d'enquête du revenu des populations coutumières et M. L. Baeck, de l'étude économique d'une cité africaine.

M. Thys, technicien, décrivit certains appareils électroniques pouvant être utilisés par des chercheurs en sciences humaines.

\title{
East African Institute of Social Research
}

A CONFBRENCE was held at the East African Institute of Social Research, Makerere College, Kampala, from 30 December 1954 to 5 January 1955. The meeting was attended by the majority of the research workers attached to the Institute, by members of the Makerere College staff, and by a number of officials of the Uganda Protectorate government. Most of the papers read concerned field-work in progress, and Fellows working on the Carnegie leadership project reported on their research in North Nyanza province of Kenya, and in Buganda. One session of the conference was devoted to economic problems, one to psycho$\operatorname{logy}$, one to clan structure, and another to land tenure. It is not intended to produce a formal report of the conference.

\section{The West African Science Association}

The West African Science Association was founded in October I 953 to encourage scientific research throughout West Africa and to enable scientists in the fifteen countries which make up this part of Africa to keep in touch with each other's work. The Association meets the needs of its members by holding regular meetings at the University College of the Gold Coast for the reading and discussion of papers, and by producing a journal. The journal not only publishes members' research work but records the papers read and the discussions held at meetings; in this way it serves the great majority of members who are unable to attend meetings.

The journal is published annually at the moment but it is hoped to produce two parts a year in the near future. Original papers are published in English, French, and German. The Association caters for Archaeology, Agriculture, Botany, Forestry, Geography, Geology, and Zoology. Papers on West African work on these subjects are thus readily available within one journal and not scattered through a number published in different parts of the world.

The annual subscription is one guinea (2Is.) per annum for individual members and for corporate bodies. Applications for membership and all inquiries should be made to the Treasurer, Mr. M. M. Anderson, c/o Geology Dept., University College, Achimota. The headquarters of the Association is at the University College, but it is an independent body which is, however, able to call upon many of the facilities of the college.

\section{Rhodes-Livingstone Museum}

THE Report of the Rhodes-Livingstone Museum for the year ended December 1953, besides an account of activities and developments during that year, includes a statement of the Tenyear Development Plan for the museum, which was submitted in December 1952 and is now being implemented. The museum owed its origin to the suggestion in 1930 of the then Secretary for Native Affairs that a sum of $£$ roo should be included in the Government Estimates for that year for the purchase of ethnological specimens for a museum. The collections were first displayed to the public in 1934 , and included a number of letters and other relics of David Livingstone. The new museum was named the "David Livingstone Memorial Museum' and a part-time Curator was appointed. In 1937 the museum was incorporated 